An International Journal of Language, Literature and Gender Studies (LALIGENS), Ethiopia

Vol. 4 (1), Serial No 9, January, 2015:23-33

ISSN: 2225-8604(Print) ISSN 2227-5460 (Online)

DOI: http://dx.doi.org/10.4314/laligens.v4i1.2

\title{
Religion in Nigerian President Olusegun Obasanjo's Political Discourses
}

\author{
Emeka-Nwobia, Ngozi U. \\ Department Languages and Linguistics \\ Ebonyi State University, Abakaliki \\ Ebonyi State, Nigeria \\ Phone: +234-8033441386 \\ E-mail: ngozinwobia@gmail.com
}

\begin{abstract}
The work is a study on how former Nigerian President Olusegun Obasanjo utilized religious language in his political speeches. Religion is an integral part of a people's culture which has an inseparable influence on the politics, economy and society in general. Language on the other hand provides the conduit for performance and expression of religion and religiousness; as well as political ideologies. The data consists of Obasanjo's speeches delivered on 29th May 1999 and 2003. Working within the tenets of Critical Discourse Analysis, the paper interrogates the trajectory in language, religion and politics in Nigeria. It probes into the role of religious references and statement in governance; how socio-religious identities can be negotiated linguistically through induced emotions, and also the patterns and usage of religion by President Obasanjo as a persuasive strategy in political communication. Our findings reveal that such references were utilized to establish affinity with the listeners; appeal to ideological sense; beatify his seat as sacred and to subtly manipulate the listener into agreeing with his ideology.
\end{abstract}

Key Words: Discourse; Religion; Critical Discourse Analysis; Inaugural Speeches; Political Discourse 


\section{Introduction}

The concept of religion, religious references and imageries in politics and political discourses may appear as distinct concepts but their inseparableness is becoming more glaring. Religious references, imageries and languages are becoming so fascinating and permeating presidential discourses such that even the secular do not raise eye brow on hearing them. Presidential Inaugural speeches are always replete and intertwined with religious references such that it appears appealing and as an instrument of unity and a common belief and identity. In spite of the overwhelming credence and popularity of the place of religion in public discourse, the field of remains impoverished due to lack of patronage by scholars and researchers especially in Africa. This interrogates how Olusegun Obasanjo utilized religious rhetoric, imageries and references as persuasive devise in a country characterized by diverse languages and ethnic leanings.

Researchers and scholars have been patronizing the study of rhetoric and persuasion in political discourse, Druckman, 2004; Lau and Redlawsk, 2001), but only few have devoted their time to study religious rhetoric (Chapp 2008). This therefore makes for the paucity of literatures on the study of religious rhetoric, This gap is alarming considering the number of studies on the use of persuasion and rhetoric in political discourse analysis as manipulative tools to persuade voters of their plans, agenda and programme This paper explains the interrelatedness between the linguistics parlance of rhetoric, and the relationship between religious predispositions and political preferences. It investigates how socio-religious identities can be expressed linguistically through induced emotions. Chapp (2007) observes that the American presidential rhetoric is saturated with reference to God, religious imageries and generating sense of divine purpose. He notes there are two distinct types of religious identity are inherent in the campaign discourse of Americans. They are; Secterian Identity: this identity is used to identify the distinct denomination and interest based religious group. For instance Catholics, Baptists, Pentecostals and various interest groups. Banal Identity; this suggests a common religious belief and heritage practiced / owned by the white Americans. At some points in American history, different presidents visibly utilized religious rhetoric in their political discourse. Fisher (2013: 23) elucidates that "religious rhetoric in electorate discourse is a unifying and galvanizing implement for the amalgamation of otherwise disparate American interest".

\section{The Role of Religion in Political discourse}

There have been series of debates on the role of religion in public sphere. Some scholars have examined a few countries that claim to have a clear-cut distinction in the assignment role in religion and the state (West 2009, Fox 2006). This somewhat 
separation of role of the role of religion in politics has been a resonating argument. Adogame's (2012) has a varied opinion on that and states that religion is an integral part of a people's way of life which has an inseparable influence on the politics, economy and the society in general. Religion is actually perceived as a place which can help individuals or groups beyond the evil shock of societal happening to adjust to their normal lives.

\section{a. Religious Rhetoric}

Language is imperative in political discourses. It gives voice to the expression of political wills and opinions. It is a conduit for transmitting political agenda and paves way into the emotion of the voters to influence their acceptance and evaluation of the political condition. It also provides means and acts as conduit for the expression of religion and religiousness. The work looks at how religious languages are utilized by the political class in the delivery of their rhetoric. This explains why people of same religion see themselves as sharing same identity. It is a bond and a tie that holds people who would have been considered separate together as one. For instance, the Christians in Europe are bound to those in the Latinos; the Jews are bound to the Hebrew and the Muslims to the Islamic world and the Arabic language.

There is the existence of civil religion; one that transcends beyond denominational difference. Wald K. (2003:55) defines it as the "idea that a nation tries to understand its historical experience and national purpose in religious term". Hunter (1991) believes that this is responsible for religious electoral cleavages. Nigeria just like most African nations believes in the existence of God who is the Supreme Being, the creator who has divine authority and of whom all blessings come from. This common believe by this secular entity suggests that Nigeria believes and imbibes the concept of civil religion; this probably accounts for the oat taking during the swearing in ceremony which is usually sealed with the expression "so help me God".

\section{b. Social Identity}

This is very important in taking any political decision. Chapp noted that for one to be religious does not really imply social identity but Emmons and Paloutzian (2003) observe that religion plays a role in social identity. This can come in the form of people seemingly favouring members of their religious group (in-group favouritism). There are kinds of affiliation/ affinity and bias usually towards one's social group. Individual's affinity to social group tend to influence political opinion or stand. Political success can be achieved by one's ability to appeal to the voter's social identities. It is often utilized by the political elites. Religious languages, symbols, references, imageries and references to God are usually often used by politicians to elicit favours from voters. Cochran and Beeghley (1991) observe that religious beliefs 
serve as yard sticks from which issues are measured or viewed from. They carve a frame of reference standpoint/ perspective.

\section{Theoretical Framework}

The work is anchored on Critical Discourse Analysis, proposed by Norman Fairclough. Critical - this has to do with unravelling power relations by means of language. Discourse refers to language in use. It can be in the form of spoken (talk) or written (text) form. Discourse analysis transcends beyond sentential level to the happenings of language that cannot be sampled out in a sentence or clause. This is because language cannot be adequately / exhaustively studied in isolation without reference to the context of the utterance. CDA is not only interested in the description and interpretation of discourses in social context, but also offers an explanation of why and how discourses work (Rogers 2004:2).

Gee (2000)'s perception of discourse has been greatly influence and shaped by Michel Facoult's view who sees Discourses as characteristic ways of talking and writing about, as well as acting with and toward, people and things. These characteristic ways are circulated and sustained within various texts, artefacts, images, social practices, and institutions, as well as in moment-to-moment social interactions. According to him, discourses cause certain perspectives, phenomenon and states of affairs which were otherwise seen as deviant to be construed as the norm and vice versa (Gee: 2000).

\section{Data}

The corpus of this research are the two inaugural speeches of former Nigerian president Olusegun Obasanjo delivered at the eagles Square, Abuja , Nigeria, on $29^{\text {th }}$ May, 1999 and $29^{\text {th }}$ May, 2003., following his swearing in as President of Federal Republic of Nigeria.

\section{Discussion}

\section{a) President Obasanjo and Nigeria Socio-religious Space}

Obasanjo was born in Abeokuta in Ogun State, Nigeria on $5^{\text {th }}$ March, 1937. He was the fourth military head of state of Nigeria and Commander in Chief of the Armed forces, from -1976 to 1979 . He started his political career when he was appointed as the federal commissioner for works and housing (which is now known as minister) from January - July, 1975. From 1975-1976 he was the chief of staff supreme headquarters of the Nigerian Army. He became the Head of state and commander in chief of the Nigerian Armed Forces on $3^{\text {rd }}$ February, 1976 following the assassination of Gen, Murtalla Mohammed on the same day. Obasanjo got promoted to a General in the Nigerian Army in 1979 before he voluntarily retired in October 1979. 
Obasanjo's personality is crucial in Nigeria political space because he has a history of successfully organising election and handing over power to a civilian president, Alhaji Umar Usman Shehu Shagari on $1^{\text {st }}$ October, 1979. He also took successfully became the democratic president of Nigeria and sworn into power on May 29, 1999 after several years of military dictatorship. He had an overwhelming victory over his second runner up - Chief Olu Falae in February 27, 1999 election that brought him into power and on 29th May, 2007 handed over to his successor a civilian president, Shehu MusaYar'Adua after an election.

\section{b) Obasanjo and his Religious/ Theological Leaning}

Immediately after leaving office as Nigerian president, Olusegun Obasanjo enrolled to pursue a post graduate diploma in Christian theology from the national open university of Nigeria. His reasons for this quest, The Nation of 22/11/2007 cited him to have said; "The decision was borne out of my desire and yearning to continue to have an interpretative understanding of the nature and concept of God within the context of Christianity". He reiterated that his passion for the course started when he was a Sunday school teacher. Obasanjo explains further that;

When upon my retirement from active service on May 29, I enrolled for the postgraduate diploma in Christian Theology at the National Open University of Nigeria; many Nigerians were astounded by my decision. Some cynically derided it and laughed at the move. Of particular interest to many was my chosen course of study." "I have always enjoyed Theology and this is an opportunity to acquire more knowledge on the course.

http://nm.onlinenigeria.com/templates/?a=10036

\section{Discursive Strategies in the Speeches}

The work examines how the political class utilized religious references and language in their political speeches and how the general populace respond to their expressions. It captures the premium importance placed on the use of religious rhetoric by presidents in the political discourse.

\section{i. Reference to God and Portrayal of Self as Saviour}

It is pertinent to note that Obasanjo commenced his first public speech as a newly sworn in president of Nigeria, with reference to God. This is symbolic as he portrays God- the divine being as his source of strength and the giver of power and authority to whom He wills. He claims that his election is by destiny as designed by God.

F ELLOW Nigerians, we give praise and honour to God Almighty for this day specially appointed by God Himself. Everything created by God has its destiny and it is the destiny of all of us to see this day. 
Obasanjo utilized the utopic rhetoric in the portrayal of self as a messiah. He gives a positive image of self as a saviour that has come to rid the country of the decadence of military rule and its consequent outcome of corruption; Just as Jesus Christ who came to redeem mankind from the bondage of sin.

Obasanjo in his word states;

our leadership regards corruption as the antithesis of development and I would like to assure you that we are determined to fight the evil to a standstill. For starters, we have been able to put in place an anti corruption commission which unfortunately has had to cope with legislative and constitutional hurdles.

In his first inaugural speech titled "We will Heal Nigeria", the president portrays himself as a healer, physician, saviour and messiah that the ailing country needs to restore her ailing economy, security, education, infrastructure, agriculture and the entire masses from the hurt inflicted by past administrations and the just concluded electioneering process. He further notes that Nigerians breathed a sigh of relief to usher in the new dawn with "never again". The president boasts that his administration has come to enthrone transparency, accountability and responsible leadership. This he feels can be achieved by appointing people of reputable character to man the different ministries in order to ensure that due process was upheld in the award of contracts, supplies and purchases.

The president further portrayed himself as a messenger sent to rid Nigeria of corruption. He claims that thirty nine cases of corruption has been brought to court for prosecution as against none ever recorded for twenty years preceding his administration. This therefore put him in positive light as having a zero tolerance for corruption and corrupt officers.

\section{ii. Biblical Reference to Psalm 23}

In his first inaugural speech, Obasanjo made reference to a biblical quote in Psalm 23

Thereafter, you the good people of Nigeria elected me, a man who had walked through the valley of the shadow of death, as your president as your president to head the democratic civilian administration

He referred to himself as having walked through the shadows of death. He was only unwinding history and recounting his life experience of being lose to death and surviving the pang of death. It is worthy to note that Obasanjo was condemned by the former military dictatorship of Abacha to death but was later reversed to fifteen years imprisonment. Obasanjo was granted bail/ amnesty and from there he contested for the seat of Nigerian presidency. The analogy is not far from reality, because he would have 
been death if providence did not take its toll with the sudden death of Abacha. The use of this biblical reference is to appeal to the conscience and emotions of the listeners and to make them believe that it is God that has kept him thus far in order to fulfil the sole purpose of salvaging the decadence already perpetrated by the military juntas. This is a strong strategy especially with the religious vulnerability of Africans especially Nigerians.

Thereafter, you the good people of Nigeria elected me, a man who hac walked through the valley of the shadow of death, as your President, tc head a democratic civilian administration. I believe that this is wha God Almighty has ordained for me and for my beloved country Nigeric and its people. I accept this destiny in all humility and with the ful belief that with the backing of our people we shall not fail.

I wish, at this point, to thank all you good Nigerians for the confidence reposed in me.

In line 5 of the above excerpt, Obasanjo noted that he accepted the election, which he referred to as destiny in all humility. This aligns with Beard (2001) assertion that politicians almost always portray themselves as humble in order to justify the confidence of the populace as well as portraying themselves as down to earth, having listening ears and worth listening to because of their humility.

This speech is replete with references to God and the use of religious imageries.

We thank God that their sacrifice has not been in vain

Obasanjo also recognizes and eulogizes the creative and supremacy of God when he noted that, "Nigeria is wonderfully endowed by the Almighty with human and other resources". According to him the abundant natural resources found in Nigeria are free gifts from the creative might of God.

\section{iii. Extolling Good Virtues}

Just like most politicians, Obasanjo in his speeches extolled the good virtues. He decried the activities of past leader who promoted evil and avoided men of integrity (he referred to them as good men). In his words,

Good men were shunned and kept away from government while those who should be kept away were drawn near.

Obasanjo is so prolific in his referrals to God, good, bad and other biblical virtues like patience, morals, spirituality, revival, makes references to good, bad and evil. To the general public that elected him, he sees them as good. 


\section{iv. Alignment with the Masses}

Obasanjo also gave an impression of aligning with the masses. He echoes that the task of governance is an onerous task which he cannot pursue alone, but requires the cooperation of all the citizenry. He notes,

I am not a miracle worker. It will be foolish to underrate the task ahead. Alone, I can do little.

This statement has a biblical undertone where Jesus says that "without me you can do nothing".

Obasanjo went on to make references to God as his guide. This is a rhetorical strategy common to politicians as a means of exonerating themselves from future mistake and pushing blames to God whom they recognise as the supreme being who was there to guide; and the leader was just a mere mortal following the guidance and dictates of God.

This time, however, the results of your sacrifice and patience will be clear and manifest for all to see. With God as our guide, and with 120 million Nigerians working with me, with commitment, sustained effort, and determination, we shall not fail.

The Nigerian president utilizes religious references as a means of legitimizing the acts and ends of political actions.

\section{v. Restoration of Confidence in Government}

Nigeria had been faced with many years of military dictatorship, interim government and various forms of political instability. The governed had lost faith in the government. The newly sworn in president cries out soliciting for the cooperation of the masses, promising that his song is going to be different from the norm.

I am very aware of the widespread cynicism and total lack of confidence in government arising from the bad faith, deceit and evil actions of recent administrations.

The president went further to categorize how he was going to restore the people's confidence in the government. He noted that he was going to use men and women of proven integrity. An analogy is here drawn from the bible in the book of Daniel when king Nebuchadnezzar deployed some Hebrew men of proven integrity in the form of Daniel, Shedrack, Meshach and Abednego.

I will need good men and women of proven integrity and record of good performance to help me in my cabinet 


\section{vi. Public Reconciliation}

I am determined to stretch my hand of fellowship to all Nigerians regardless of their political affiliations. I intend to reconcile all those who feel alienatec by past political events and I will endeavour to heal divisions, and to restort the harmony we used to know in this country.

It is our firm resolve to restore Nigeria fully to her previous prestigious position in the comity of nations.

In the example above Obasanjo talks of leaving no stone unturned in ensuring national reconciliation. He used biblically and religious words/expressions like; fellowship, reconcile, heal, pray, revival and restoration.

\section{vii. Power of Repetition and a Call to Pray}

Repetition is a major gimmicks associated with religious rhetoric to create lasting and impressive impression on the listener. Obasanjo utilized it in the utterance below;

it is good for us. It is good for Africa, and it is good for the world.

I call on all Nigerians but particularly on our religious leaders to pray for moral and spiritual revival and regeneration in our nation.

Obasanjo recognizes the inseparable influence of religious affiliation to the Nigerian people, thereby extending an invitation to religious leaders to pray for moral and spiritual revival and regeneration of our country.

Obasanjo utilized religious rhetoric, imageries and references to God, in order to indoctrinate his supporters and to beatify his seat as a sacred platform. This portrayed his image as an ordained ruler on a quasi- sanctified platform (like the Bible Israelite kings), rather than an elected leader. Chapp (7) in his study of American presidential religious rhetoric observe that such references evoke civil religion; which he explained in his words as a, "broad religious identity [that] unites virtually the entire nation" .

In September 1991, the Democratic candidate for the governor of Texas, USA, made this statement, "issues are important, but they are as important as the fact that this is an opportunity to vote for one of your own". The phrase, "one of your own" connotes identity and alignment to an ingroup. He recognizes the importance of social identity and group appeals in eliciting voters support. In social identities, relevant political choices could be influenced by factors like age, class, ethnicity, partisan groups and religion. These are social variables which align on a social category. Members see themselves as sharing same social organisation. Stet and Burke (2000) identify that selfesteem is a strong motivation to the outcome and group membership is one of the great 
sources of self-esteem. They tried classifying the difference between sectarian references and banal references. Sectarian references are used to differentiate them from non-members (out-group) .

Leege et al. (2002) for instance believes that "Through the manipulation of various psychological mechanisms rooted in primary group attachments, political elites attempt to frame issues in such a way to mobilize specific portions of the electorate and demobilize other portions". This accounts for how the connection between religious attachment and voting behaviour in American politics. This relies heavily on religious rhetoric from political elites.

\section{Conclusion}

Language and religion are two potent forces in the construction of national identity especially in a country like Nigeria (the most multilingual country in Africa with about 450 to 500 distinct and identified languages Elugbe (2012). Religion plays a striking role in Nigeria socio-political space because it encapsulates one's totality about his origin, stay and end of life. Religion provides succour to the story of our existence and day to day life. Religion is a linguistically unifying force and at the same time it is also a divisive force; language on the other hand provides the conduit for expression and performance of religion and religious rituals.

Religious rhetoric in presidential discourse is a unifying and an agglutinating instrument utilized by Obasanjo to bring people of diverse beliefs and values that make up the geographical entity called Nigeria, together. Nigeria is a heterogeneous nation, in fact, about the most multi lingual and multi -ethnic nation in Africa, with between 450 and 500 linguistic and ethnic groups. The country has witnessed diverse ethno-religious clashes, conflicts and wars; such that the issue of religion is being traded with caution. Obasanjo's skill in deploying religious references in his discourses is unique as this acts as a tool of unification of seemingly disparate individuals, blocs and groups that make up the country.

He evoked God, not only as in a personal prayer, invocation and supplication but also as a unifying force that protects the nation and its citizenry, as well as pilots and directs their course.

Though the multi-ethnic and multi-religious diversity of Nigeria eco-space is prone to anomaly, yet the religious references are still ubiquitous and indispensible in presidential inaugural addresses. This paper recognizes that there is a strong tie and alignment between democracy and religious; language on the other hand provides the conduit for expression of these cleavages. Religious rhetoric permeates political discourse especially at the intersection of social and political mores. This work contends that language and religion are integral part of Nigerian political discourses 
and which aligns with Adogame's (2012)'s assertion that religion is an integral part of a people's culture which has an inseparable influence on the politics, economy and the society in general on the hand all these thoughts, programmes, beliefs and leanings can only be expressed by linguistic resources.

\section{Acknowledgement of Support}

Many thanks to the SSRC with generous funding by Carnegie Corporation of New York for providing the fund for the research.

\section{References}

Adogame, A. (2012). Dealing with Local Satanic Technology: Deliverance Rhetoric in the Mountain of Fire and Miracles Ministries. The Journal of World Christianity 2012, Volume 5:1 pp 75-101

Chapp, C. B. (2012). Religious Rhetoric and American Politics: The Endurance of Civil Religion in Electoral Campaigns. Ithaca: Cornell UP, Print.

Fisher, J. (2013. Religious Rhetoric in US Presidential Inaugural Addresses: A Meta Analysis. Emergence Issue 4, 20-34

Holt Ron (2006). “A Socio-linguistic Approach to Religious Language”. Australian e-Journal of Theology 6( Feb, 2006).

Leege, D. C. and L. A. Kellstedt (Eds.). 1993. Rediscovering the Religious Factor in American Politics. New York: M. E. Sharpe.

Leege, David C., Kenneth D. Wald, Brian S. Krueger, and Paul D. Mueller. 2002. The Politics of Cultural Differences: Social Change and Voter Mobilization Strategies in the Post-New Deal Period. Princeton: Princeton University Press.

Leege, D.C. and Lyman A. Kellstedt (Eds.). 1993. Rediscovering the Religious Factor in American Politics. New York: M. E. Sharpe.

Leege, D. C., Kenneth D. Wald, Brian S. Krueger, and Paul D. Mueller. 2002. The Politics of Cultural Differences: Social Change and Voter Mobilization Strategies in the PostNew Deal Period. Princeton: Princeton University Press.

Stets J.E. and Burke PJ, (2000), “ Identity Theory and Social Identity Theory”. Social Psychology Quarterly Vol 63; no3. 224-237

Joshua Fischer Religious Rhetoric in US Presidential Inaugural Addresses, A Meta-analysis. Accessed November, 2013 from http://nm.onlinenigeria.com/templates/?a=10036\#ixzz35CcHxky4 